\title{
TILMICOSIN INTAKE AND DISTRIBUTION IN THE BODY OF BROILER CHICKENS WITH ORNITHOBACTERIOSIS
}

\author{
A. M. TYSHKIVSKA, Graduate Student, Department of Pharmacology, \\ Parasitology and Tropical Veterinary Medicine \\ http://orcid.org/0000-0003-4419-2174 \\ V. B. DUKHNYTSKYI, Doctor of Veterinary Sciences, Professor, Department \\ of Pharmacology, Parasitology and Tropical Veterinary Medicine \\ http://orcid.org/0000-0002-9670-1244 \\ National University of Life and Environmental Sciences of Ukraine, \\ 15 Heroiv Oborony st., Kyiv 03041, Ukraine \\ E-mail:annatyshkivska@gmail.com,dukhnytskyjvb@ukr.net
}

\begin{abstract}
One of the main indicators that determine the effectiveness of the antibiotic in the body is its ability to penetrate and accumulate in high concentrations at the sites of the pathological process. The article presents the results of studies of the intake, distribution, and excretion of tilmicosin phosphate - the active substance of the antibiotic Tilmox $25 \%$ from the body of broiler chickens (Cobb-500 cross) with ornithobacteriosis. It was found that in 24 hours after the start of the feeding Tilmox $25 \%$ solution to broiler chickens with ornithobacteriosis, most tilmicosin phosphate was contained in the lungs, while in the liver less than 1.6 times, kidneys 3.0 times, heart muscle - 3.4 times, pectoral muscles -3.5 times than in the lungs. After 48 and 72 hours, the tilmicosin content increased in all studied organs but the pattern of its distribution was the same as after 24 hours. Tilmicosin phosphate levels in the lungs exceeded the values in the liver, kidneys, heart, and pectoral muscles by 1.8 times, 2.7, 2.9, and 3.9 times, respectively, at 72 hours of the experiment. At 96 hours, tilmicosin levels were highest in the pectoral muscles, kidneys, liver, and lungs, and only slightly less in the heart than in previous research periods. The obtained results testify to the organ affiliation of tilmicosin phosphate to the lung tissues in broiler chickens with ornithobacteriosis. In a day (120 hours of the experiment) after discontinuation of Tilmox $25 \%$, the content of tilmicosin phosphate in the lungs, liver, kidneys, heart, and pectoral muscles of broiler chickens was 53\%, 50,57,68, and 34\%, respectively, in comparison with values after 96 hours. The Ornithobacterium rhinotracheale sensitivity to tilmicosin and its distribution in maximum amounts in the lungs of broiler chickens with ornithobacteriosis provided a therapeutic effect, which was confirmed by microscopic studies.

Studies on the pharmacokinetic properties of tilmicosin have been performed mainly in healthy birds. Therefore, the optimization of treatment regimens of already known antibiotics, which will be based on the study of pharmacokinetic and pharmacodynamic properties not only on clinically healthy but also on diseased organisms is a relevant and important issue in the field of veterinary pharmacology.
\end{abstract}

Keywords: Tilmox 25\%, tilmicosin phosphate, broiler chickens, ornithobacteriosis, Ornithobacterium rhinotracheale, pharmacokinetics, distribution, accumulation, excretion 


\section{Introduction}

Antibiotics are a key component of modern veterinary medicine used in the treatment of animals and poultry in more than half of all diseases. They are used as a primary therapy - to destroy the pathogen and to treat patients with secondary infections, which often occur as complications of viral and parasitic diseases, mycoses, and immunodeficiency. The pharmacokinetics of the animal's interaction with the drug is studied. It describes the absorption of the drug into the blood - bioavailability, its distribution, biotransformation, accumulation, and excretion. Pharmacokinetic indicators allow the physician to select an effective drug and calculate the most optimal treatment regimen that will provide a therapeutic effect and prevent the development of bacterial resistance (Evans et al., 2002; Lalonde et al., 2007; Ronald et al., 2014).

One of the reasons for the development of bacterial resistance is the insufficient bioavailability of the antibiotic at the site of pathogen localization. This leads to the fact that the concentration required to kill bacteria is not reached in the tissues, or the drug is excreted too quickly (McClary et al., 2011).

In recent years, in European countries, including Ukraine, the semi-synthetic macrolide antibiotic tilmicosin began to actively use for the treatment of birds with respiratory diseases caused by Mycoplasma gallisepticum, Mycoplasma synoviae, Ornithobacterium rhinotracheale, Pasteurella multocida.

Desirable pharmacokinetic properties of tilmicosin include rapid absorption, good airway penetration, and slow excretion (Li et al., 2017).

\section{Analysis of recent researches and publications}

Tilmicosin is a semi-synthetic macrolide antibiotic synthesized from tylosin, with a broad spectrum of action, which has a pronounced activity against the causative agents of avian respiratory diseases - respiratory mycoplasmosis, ornithobacteriosis, pasteurellosis. Positive properties that characterize the tilmicosin pharmacokinetics are its rapid absorption after oral administration, good penetration into the tissues of the respiratory tract, in particular into the lungs and air sacs, slow excretion, which provides a pronounced prolonged effect (McClary et al., 2011; El-Mahmoudy et al., 2016; Li et al., 2017; Li et al., 2017; Timsit et al., 2017).

The tilmicosin's pharmacokinetic properties have been studied by many scientists in different dosage forms and animals of different species. In particular, in 2007, Jordanian scientists conducted studies on broiler chickens with tilmicosin phosphate in the composition of the drugs Provityl - a ready-made aqueous solution for oral administration and Pulmotyl AS - a powder for solution. The drugs were used in broiler chickens 30 days of age for 5 days. Studies have shown the tilmicosin phosphate's bioequivalence, rapid absorption, and slow excretion (Moore et al., 1996; Shen et al., 2005; Abu-Basha et al., 2007).

A pharmacokinetic study of tilmicosin was also performed in healthy pigs and infected with Haemophilus parasuis. The drug was administered orally once at a dose of $40 \mathrm{mg} / \mathrm{kg}$ body weight. Tilmicosin concentrations were determined in blood plasma at regular intervals after administration for 96 hours. The maximum serum concentration of tilmicosin in healthy animals was $1.77 \pm 0.33$ compared to 1.67 $\pm 0.128 \mu \mathrm{g} / \mathrm{L}$ in patients, indicating no significant differences between pharmacoki- 
netic profiles in clinically healthy pigs and infected with $H$. parasuis (Zhang et al., 2017; Zhang et al., 2019).

Comparative characterization of the pharmacokinetic parameters of tylosin and tilmicosin in 12 lactating Holstein cows after intravenous administration showed that the maximum serum concentrations are $1.30 \pm 0.12$ for tylosin and $4.55 \pm$ $0.23 \mu \mathrm{g} / \mathrm{mL}$ for tilmicosin. The time required to reach the peak concentration for tylosin was 2 hours, while for tilmicosin 4 hours. The half-lives were $20.46 \pm 2.08$ hours for tylosin and $26.36 \pm 5.55$ hours for tilmicosin, indicating long-term excretion of the drug and its prolonged action in animals (Ziv et al., 1995; Dimitrova et al., 2012; Avci et al., 2014).

The research results of the pharmacokinetics of tilmicosin in healthy broiler chickens, when administered orally, indicate that the drug is well absorbed from the digestive tract, and the maximum concentration in serum is reached 2 hours after ingestion. Similar results were obtained in other studies performed on laying hens and broiler chickens. In particular, the maximum tilmicosin concentration in the serum of laying hens was found after $2 \mathrm{~h}$ and was $1.28 \mu \mathrm{g} /$ $\mathrm{mL}$, in broiler chickens $-1.297 \mu \mathrm{g} / \mathrm{mL}$ (Keles et al., 2001; Kowalski et al., 2002; $\mathrm{Li}, 2003)$. Other studies have shown that with a single internal application of tilmicosin to birds, the time to reach the maximum concentration in blood plasma is 2.5 hours. The antibiotic rapidly entered organs and tissues, accumulated in macrophages and lung tissues, where its concentrations were higher than in blood plasma (El-Ela et al., 2015).

The research results of the pharmacokinetics of tilmicosin presented in the scientific literature apply mainly to healthy animals and poultry. There is no information on the intake, distribution, and excretion of tilmicosin from broiler chickens with ornithobacteriosis.

The purpose of the research is to investigate tilmicosin phosphate intake, distribution, and excretion when using it in the form of the drug Tilmox $25 \%$ in the body of broiler chickens with ornithobacteriosis.

\section{Materials and methods of research}

The research was conducted on the basis of one of the poultry farms in the Ivano-Frankivsk region. For research, 20 broiler chickens of Cobb-500 cross aged 25 days, with an average body weight of $1200 \mathrm{~g}$ were used. Bacteriological examination in birds diagnosed ornithobacteriosis, which in some individuals was complicated by Escherichia coli.

Before performing the experiment, 5 sick broiler chickens in a state of light ether anesthesia were slaughtered and the lungs and trachea were taken for microscopic examinations and the tracheal washes - for bacteriological examinations.

The effectiveness of the treatment was monitored by clinical indicators and microscopic changes in the studied organs of broiler chickens on the second and fourth days after administration of Tilmox $25 \%$. To do this, 3 chickens under light ether anesthesia were slaughtered and the lungs and trachea were removed again.

To detect the causative agent of pneumonia and aerosaculitis, from a bird slaughtered in a state of light ether anesthesia, washes were removed from the tracheal mucosa using a sterile applicator SWAB (Biomerieux). Selected material from the tracheal mucosa was sieved by direct seeding on blood agar. Cultivation was performed under microaerophilic conditions at a tempera- 
ture of $37^{\circ} \mathrm{C}$ for 48 hours. After cultivation, the growth of small matte gray colonies was found.

The two-day culture was identified by the method of MALDI TOF mass spectrometry by direct deposition.

Antibiotic sensitivity of the isolated culture of microorganisms was determined using the disc-diffusion method. From pure daily culture, a suspension was prepared in a sterile isotonic sodium chloride solution on a turbidity scale of 0.5 (according to McFarland). Mueller-Hinton blood agar (Biomerieux) was inoculated with the suspension and antibiotic discs were spread on the surface. The culture of the isolated microorganisms was cultured in Petri dishes at a temperature of $37^{\circ} \mathrm{C}$ for 24 hours. After cultivation, growth retardation zones were measured according to CLSI: M31-A3.

For studies, a solution of the drug Tilmox $25 \%$ of the AVICO trademark (active substance-tilmicosin phosphate) was used, which in an amount of $0.3 \mathrm{ml}$ was mixed with 1 liter of drinking water.

The tilmox solution was fed to broiler chickens for 96 hours instead of drinking water, according to the recommended scheme used in industrial poultry farming. For birds feeding, the complete feed was used taking into account the technological scheme of growing.

Three chickens in a state of light ether anesthesia were slaughtered in 24,48 , 72 , and 96 hours after the start of feeding a solution of Tilmox $25 \%$, and the lungs, liver, kidneys, heart, pectoral muscles were taken to control tilmicosin phosphate entry and distribution in the body of broiler chickens with ornithobacteriosis, and 24 hours after discontinuation of a tilmox solution (i.e. 120 hours after the start of the experiment) to control its content in the internal organs and excretion. Selected samples were frozen.
Tilmicosin phosphate detection by liquid chromatography spectrometry was performed after pre-extraction with acetonitrile and subsequent purification of the samples. Extraction, concentration, and purification of test samples were performed on solid-phase extraction columns. Tilmicosin phosphate was extracted from the column with eluent. Identification was carried out by retention time and quantification - by the method of external standards, by the area of peaks. Detection was performed using Waters LC-MS-MS liquid chromatograph with a Premier XE tandem quadrupole detector. The results of the study were calculated by the methods of variation statistics.

\section{Results of the research and their discussion}

Clinical examination of sick broiler chickens showed general depression, plumage, apathy, and refusal to feed. Nasal discharge and swelling of the nasal mucosa were observed in some individuals. Histological examinations of organs in broiler chickens with ornithobacteriosis revealed the presence of distinct microscopic changes. In the lungs, the lumens of most parabronchi were markedly reduced due to the swelling of their walls and infiltration, mainly by lymphocytes, among which a small number of monocytes and pseudo-eosinophils were found (Fig. 1, 2). The epithelium on the surface of the parabronchi was almost completely absent. Only a few flattened epithelial cells or their small groups were found.

Most of the air capillaries in all parabronchial complexes, without exception, were narrowed due to the marked expansion and overflow of blood capillaries. Instead, a small part of the air capillaries was clearly dilated 


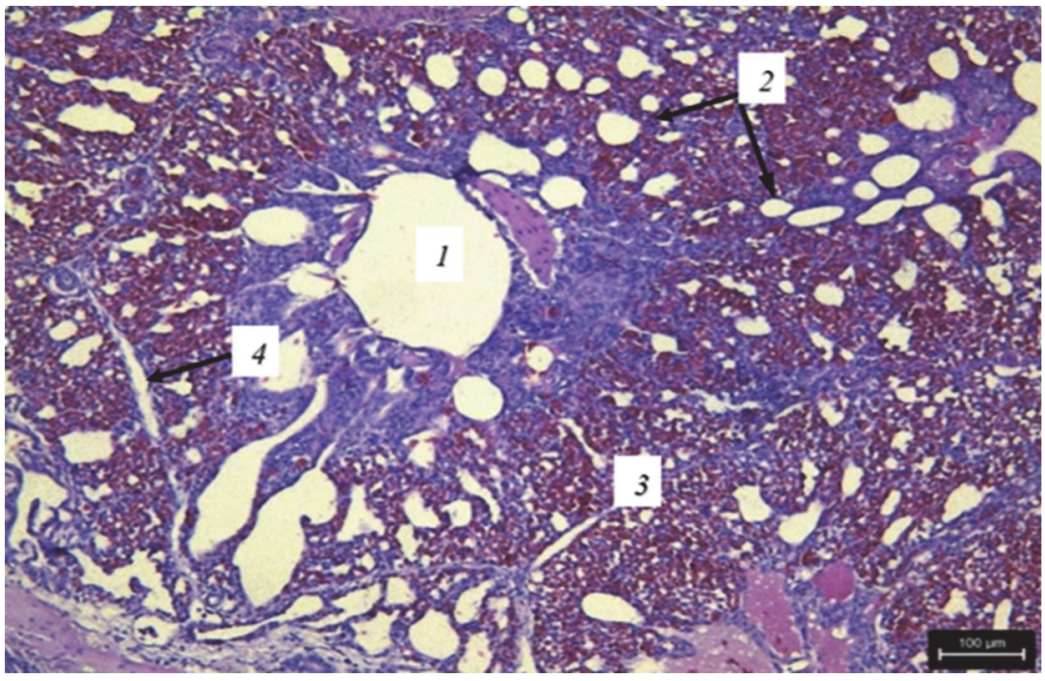

Fig. 1. The lungs of a broiler chicken with ornithobacteriosis:

parabronchial lumen (1), dilated air capillaries (2), narrowed air capillaries (3), unevenly swollen connective tissue (4). Hematoxylin Jill 2 and eosin

(Fig. 1-2), which, in our opinion, indicated a compensatory response of the lungs to the loss of a significant part of the gas exchange surface. On the surface of almost all air capillaries, the epithelium was also absent (Fig. 3).
All blood vessels of the lungs were clearly dilated, full of blood cells. In all cases, pronounced edema was found around the blood vessels, and hemorrhages were also found around some of them (Fig. 4). Hemorrhages were also

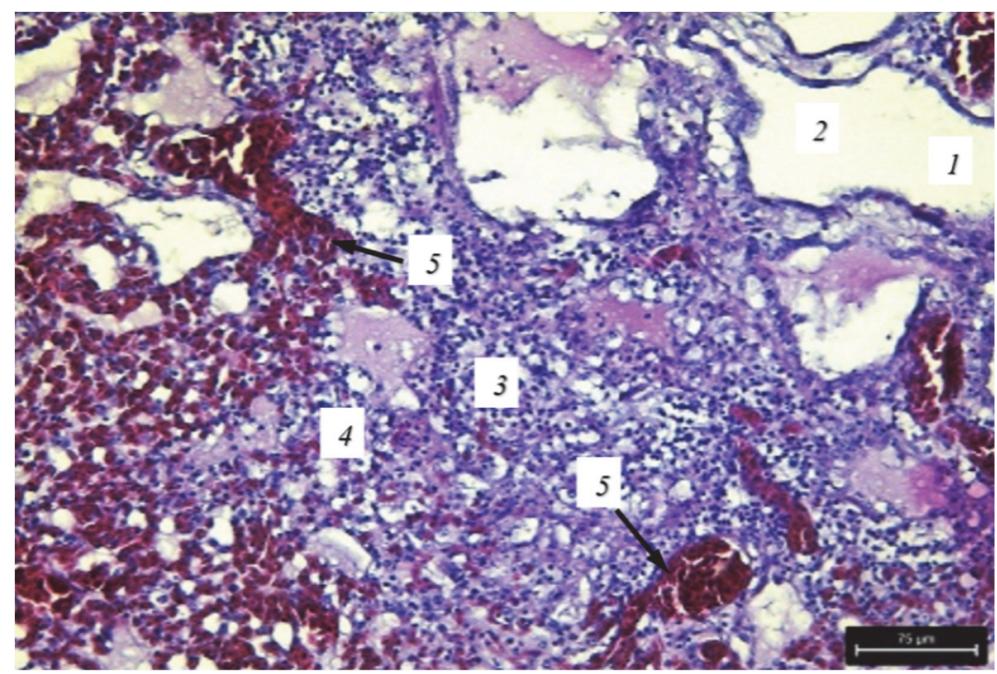

Fig. 2. The lungs of a broiler chicken with ornithobacteriosis: parabronchial lumen (1), absence of respiratory epithelium (2), lymphocytic infiltration, dilated blood-filled capillaries (3), hemorrhage (4). Hematoxylin Jill 2 and eosin 


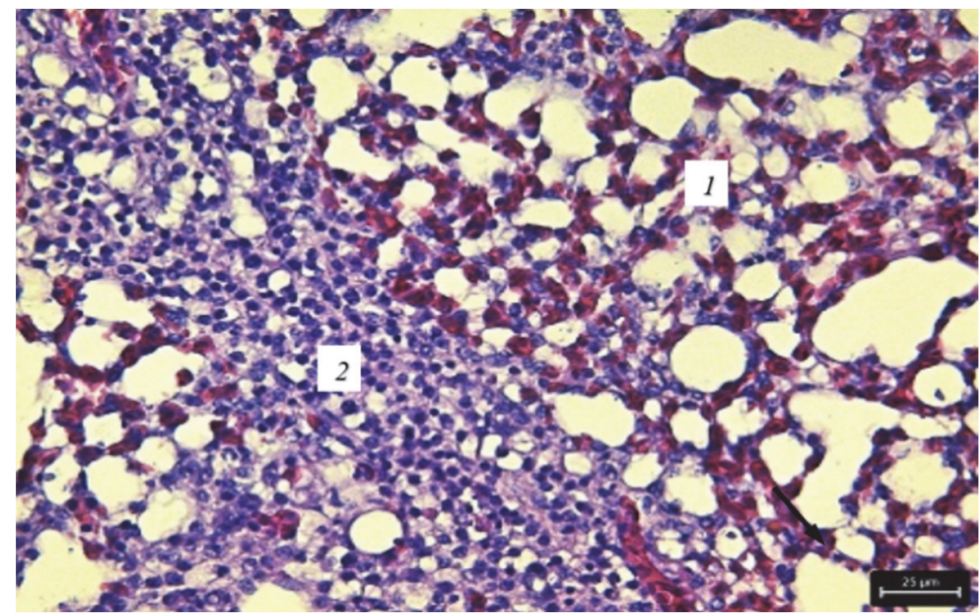

Fig. 3. The lungs of a broiler chicken with ornithobacteriosis:

absence of respiratory epithelium in the air capillary (1), edema and lymphocytic infiltration of connective tissue between two adjacent parabronchial complexes (2). Hematoxylin Jill 2 and eosi

found in the parenchyma of parabronchial complexes (Fig. 2).

The trachea was noticeably less affected than the lungs. The entire surface of the tracheal mucosa was covered with a fairly thick layer of thick mucus (Fig. 5). Part of the epithelial cells in the tracheal mucosa was destroyed and part became clearly flattened. All blood vessels of the mucous membrane were significantly dilated and overflowed with blood cells. The submucosal base was clearly swollen. Instead,

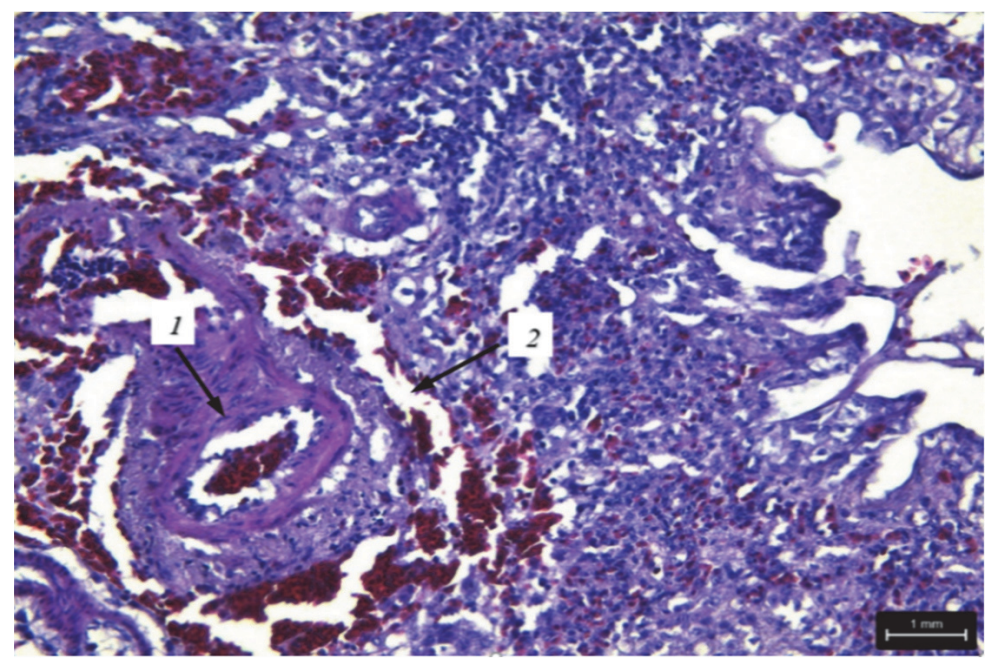

Fig. 4. The lungs of a broiler chicken with ornithobacteriosis:

dilated blood-filled artery (1), edema and hemorrhage around the artery (2). Hematoxylin Jill 2 and eosin 


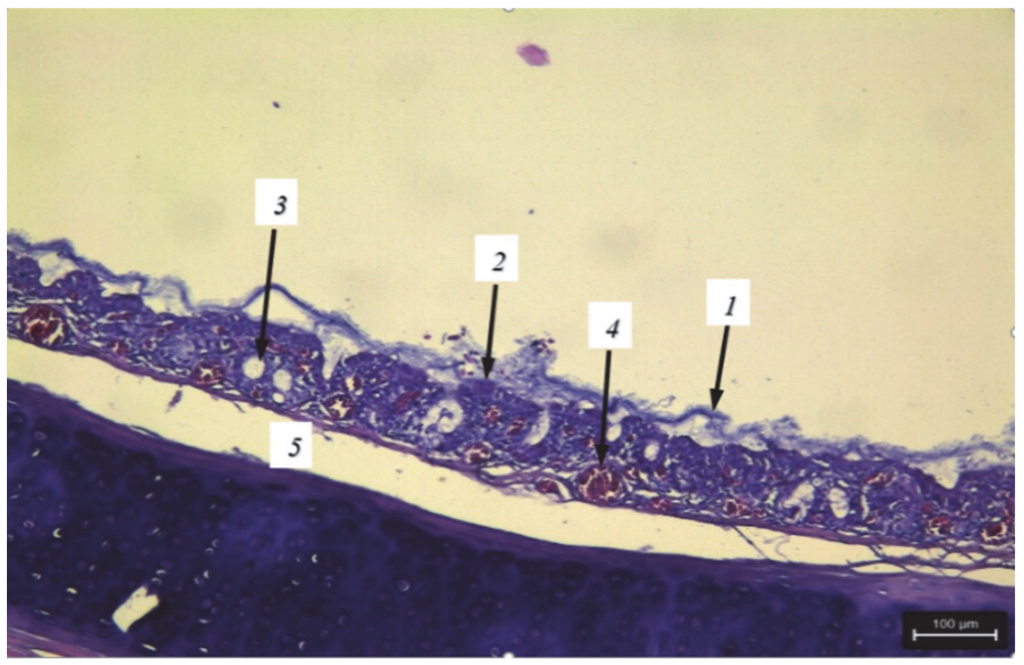

Fig. 5. The trachea of a broiler chicken with ornithobacteriosis:

mucus on the surface of the mucosa (1), destruction of the epithelium (2), foci of edema (3), dilated blood-filled vein (4), edema of the submucosal base (5). Hematoxylin Jill 2 and eosin

microscopic changes were not detected in the cartilage tissue.

Bacteriological examination with the determination by MALDI TOF mass spectrometry identified a culture of microorganisms isolated from the trachea as Ornithobacterium rhinotracheale.

According to the results of the antibiotic susceptibility reaction, it was found that the culture of Ornithobacteria isolated from the trachea is sensitive to doxycycline, tilmicosin, rifampicin, cefazolin, amoxiclav, and benzylpenicillin, moderately sensitive to enrofloxacin, and resistant to gentamicin (Table 1).

In 24 hours after the start of feeding Tilmox 25\% solution to broiler chickens with ornithobacteriosis, the highest content of its active substance (tilmicosin phosphate) was found in the lungs, much less in the liver, and least in the kidneys, heart, and pectoral muscles (Table 2). During this research period, the tilmicosin phosphate content in the lungs was 1.6 times, 3.0, 3.4, and 3.5 times higher than in the liver, kidneys, heart, and pectoral muscles, respectively (Table 2).
Feeding Tilmox 25\% solution to broiler chickens the next day was accompanied by a slight increase in tilmicosin phosphate content in all studied organs. In particular, 48 hours after the start of drinking tilmox solution, the tilmicosin phosphate content was higher in the lungs by $14 \%$, liver - by $6 \%$, kidneys - by $17 \%$, heart by $19 \%$, pectoral muscles - by $3 \%$.

As in previous study periods, 72 hours after the start of feeding tilmox solution to broiler chickens, tilmicosin phosphate was highest in the lungs, less in the liver, and least in the kidneys, heart, and pectoral muscles. Tilmicosin phosphate levels in the lungs during this study period were 1.8 times, 2.7, 2.9, and 3.9 times higher than in the liver, kidneys, heart, and pectoral muscles, respectively.

In 96 hours after drinking tilmox solution, the tilmicosin phosphate content in the lungs, liver, kidneys, and pectoral muscles reached maximum values for the entire study period and exceeded the values observed at 24 hours in the lungs by 
1. Antibiotic sensitivity of Ornithobacterium rhinotracheale culture isolated from the trachea in broiler chickens

\begin{tabular}{|c|c|c|c|c|c|c|}
\hline \multirow{2}{*}{ Antibiotic } & \multirow{2}{*}{$\begin{array}{c}\text { Code } \\
\text { (antibiotic } \\
\text { content in the } \\
\text { disk, } \mu \mathrm{g} / \mathrm{g} \text { ) }\end{array}$} & \multicolumn{3}{|c|}{$\begin{array}{l}\text { The zones' sizes interpretation } \\
\text { of growth retardation }\end{array}$} & \multirow{2}{*}{$\begin{array}{l}\text { Growth } \\
\text { retardation } \\
\text { zone, } \mathrm{mm}\end{array}$} & \multirow{2}{*}{$\begin{array}{l}\text { Research } \\
\text { result }\end{array}$} \\
\hline & & $\begin{array}{c}\mathrm{R} \\
\text { Resistant }\end{array}$ & $\begin{array}{l}\text { I Moderately } \\
\text { sensitive }\end{array}$ & $\begin{array}{c}\text { S } \\
\text { Sensitive }\end{array}$ & & \\
\hline Erythromycin & E10 & $\leq 20$ & 21-22 & $\geq 23$ & 0 & Resistant \\
\hline Enrofloxacin & EX10 & $\leq 18$ & $19-22$ & $\geq 23$ & 20 & $\begin{array}{c}\text { Moderately } \\
\text { sensitive }\end{array}$ \\
\hline Oxytetracycline & $\mathrm{O} 30$ & $\leq 24(22)$ & - & $\geq 24$ & 22 & Resistant \\
\hline $\begin{array}{l}\text { Benzylpenicillin } \\
\text { (penicillin-G) }\end{array}$ & P1 & $\leq 17$ & - & $\geq 17$ & 19 & Sensitive \\
\hline Amoxiclav & AMC30 & $\leq 15$ & - & $\geq 15$ & 28 & Sensitive \\
\hline Gentamicin & GEN30 & $\leq 23$ & - & $\leq 23$ & 8 & Resistant \\
\hline Cefazolin & CZ30 & $\leq 14$ & $15-17$ & $\geq 18$ & 22 & Sensitive \\
\hline Rifampicin & RIF15 & $\leq 16$ & $17-19$ & $\geq 20$ & 21 & Sensitive \\
\hline Doxycycline & DO30 & $\leq 20$ & $21-24$ & $\geq 25$ & 20 & Sensitive \\
\hline Tilmicosin & TL15 & $\leq 13$ & $14-20$ & $\geq 21$ & 21 & Sensitive \\
\hline
\end{tabular}

$17 \%$, liver - by $8 \%$, kidneys - by $32 \%$, pectoral muscles - by $4 \%$. The tilmicosin phosphate content in the heart muscle in this study period decreased compared to 72 hours by $29 \%$ and was even lower than after 24 hours by $4 \%$ (Table 2 ).

The obtained research results convincingly prove that tilmicosin phosphate in the body of broiler chickens with ornithobacteriosis during the period of feeding Tilmox $25 \%$ solution in maximum quantities is distributed in the lung tissue.

Although tilmicosin phosphate was distributed in maximum amounts in lung tissue, there is no reason to assert material accumulation in this organ, as its rate increased only by $17 \%$ during the period from 24 to 96 hours of drinking tilmox solution (Table 2). We believe that the tilmicosin phosphate distribution in the largest quantities in the lungs indicates its organ affiliation, which is of great practical importance in bacterial diseases of birds with respiratory lesions, in particular in ornithobacteriosis.

Higher levels of tilmicosin phosphate in the liver and kidneys than in the heart and pectoral muscles are ex-

2. Tilmicosin phosphate content in organs and tissues of broiler chickens with ornithobacteriosis while feeding a tilmox solution, $\mu \mathrm{g} / \mathrm{g}(\mathrm{M} \pm \mathbf{m}, \mathbf{n}=\mathbf{3})$

\begin{tabular}{|l|c|c|c|c|c|}
\hline \multirow{2}{*}{ Organ/tissue } & \multicolumn{5}{c|}{ Research time, hours } \\
\cline { 2 - 6 } & 24 & 48 & 72 & 96 & 120 \\
\hline Pectoral muscles & $3.18 \pm 0.02$ & $3.27 \pm 0.02$ & $3.29 \pm 0.03$ & $3.31 \pm 0.01$ & $1.14 \pm 0.01$ \\
\hline Kidneys & $3.66 \pm 0.28$ & $4.27 \pm 0.13$ & $4.78 \pm 0.12$ & $4.84 \pm 0.05$ & $2.75 \pm 0.15$ \\
\hline Liver & $6.73 \pm 0.27$ & $7.11 \pm 0.07$ & $7.22 \pm 0.05$ & $7.25 \pm 0.07$ & $3.65 \pm 0.05$ \\
\hline Lungs & $11.05 \pm 0.04$ & $12.57 \pm 0.34$ & $12.72 \pm 0.28$ & $12.91 \pm 0.06$ & $6.88 \pm 0.37$ \\
\hline Heart & $3.25 \pm 0.03$ & $3.86 \pm 0.15$ & $4.37 \pm 0.55$ & $3.11 \pm 0.03$ & $2.13 \pm 0.03$ \\
\hline
\end{tabular}




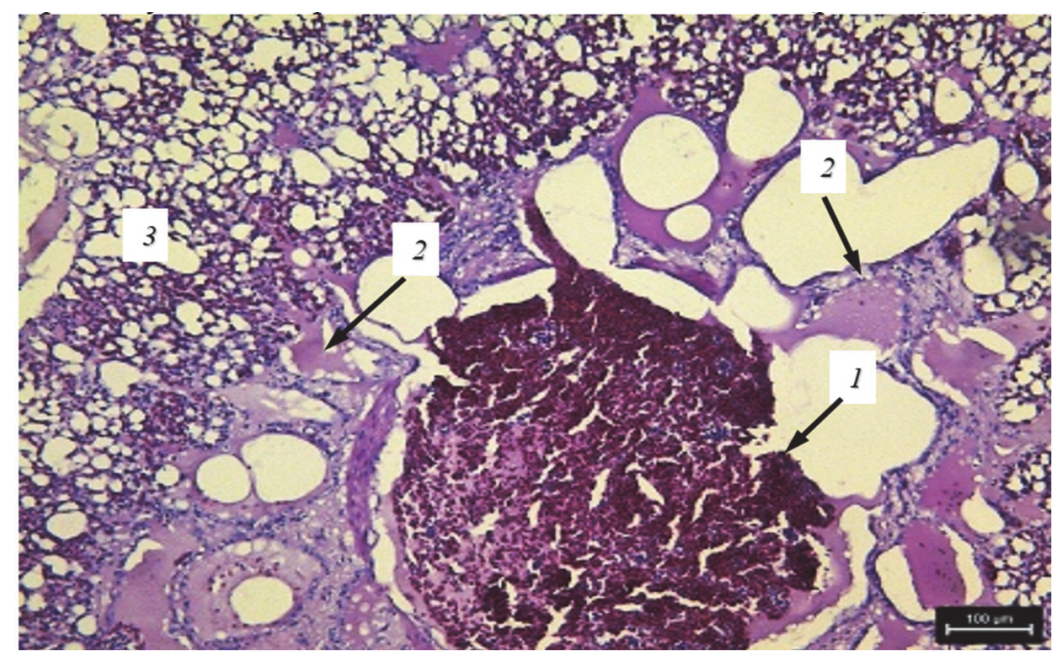

Fig. 6. The lungs of a broiler chicken with ornithobacteriosis on the 2 nd day of the treatment with tilmicosin: cellular detritus and red blood cells in the lumen of the parabronchia (1), edema of the parabronchial wall (2), air capillaries (3). Hematoxylin Jill 2 and eosin

plained by better blood supply to these organs, as well as participation in the processes of biotransformation and excretion from the body.

After the application of tilmicosin to broiler chickens, cellular detritus and erythrocytes were detected in the lungs and lumen of the parabronchi for the second day, which, in our opinion, testified to the processes of organ cleansing (Fig. 6).

No marked inflammatory reaction was observed, although the walls of the

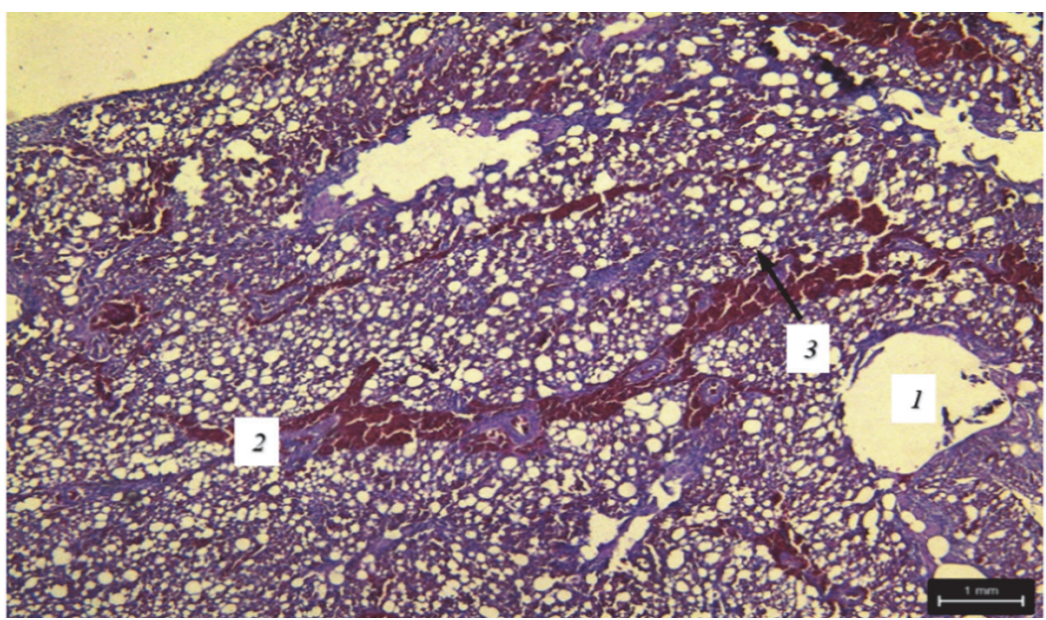

Fig. 7. The lungs of a broiler chicken with ornithobacteriosis on the 4th day of the treatment with tilmicosin: lumen of the parabronchia (1), dilation and overflow of blood vessels (2), air capillaries (3). Hematoxylin Jill 2 and eosin 


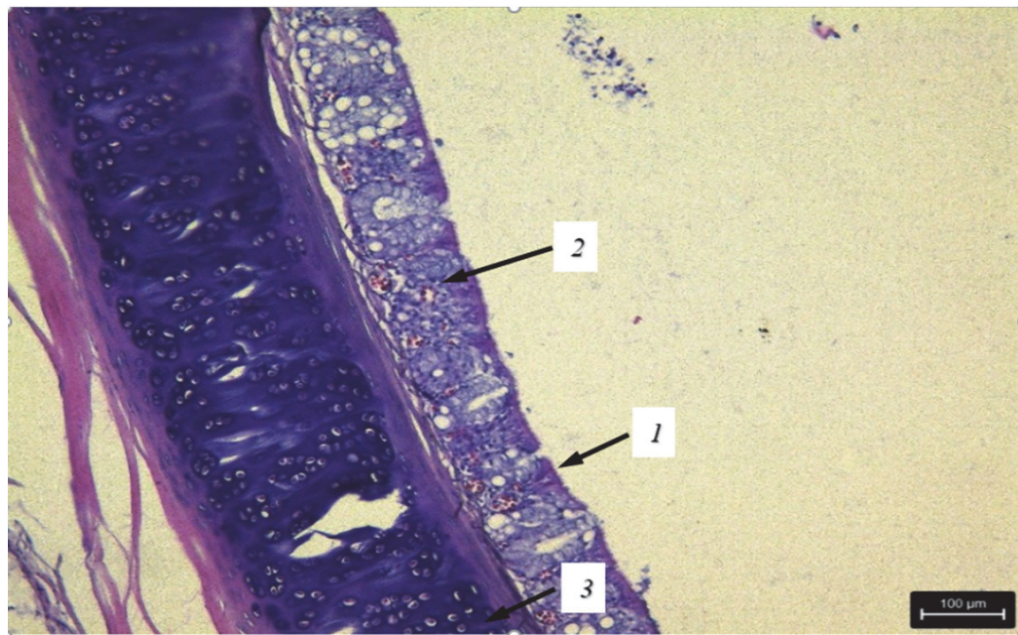

Fig. 8. The trachea of a broiler chicken with ornithobacteriosis on the 4th day of the treatment with tilmicosin: epithelium of the mucous membrane (1), mucous membrane (2), cartilage (3). Hematoxylin Jill 2 and eosin

parabronchi were swollen. The air capillaries were dilated. Small groups of narrowed air capillaries were found only in some places (Fig. 6). Such changes testified to more intensive functioning of the lungs.

Only slight dilation and overflow of mucosal blood vessels were observed in the trachea.

On the 4th day after the tilmicosin application, there was the only hyperemia in the lungs (Fig. 7). In the trachea, no microscopic changes were detected (Fig. 8).

After cessation of feeding broiler chickens with a tilmox solution, the content of its active substance (tilmicosin phosphate) in the internal organs has decreased (Table 1). Thus, in a day after discontinuation of Tilmox 25\% (120 hours of the experiment), the tilmicosin phosphate content in the lungs, liver, kidneys, heart, and pectoral muscles was lower than in 96 hours by $47 \%, 50$, 43,32 , and $66 \%$, respectively, which, in our opinion, provides a long-lasting antimicrobial effect.

\section{Conclusions and future perspectives}

In the lungs of broiler chickens with ornithobacteriosis, microscopic changes were characterized by a decrease in the lumen of the parabronchi due to swelling of their walls and infiltration, mainly by lymphocytes, lack of epithelium on the surface of the parabronchi; narrowing of air capillaries in parabronchial complexes; hemorrhages in the parenchyma of parabronchial complexes; dilation of the vessels in the lungs, their overflow with blood cells and edema around the vessels.

Microscopic changes in the trachea were characterized by the destruction of the part of epithelial cells in the mucosa and the rest of them became clearly flattened; swelling of the submucosal base; dilation and overflow of mucosal blood vessels with blood cells.

When feeding Tilmox 25\% solution to broiler chickens with ornithobacteriosis according to the recommended scheme, the highest content of its active substance (tilmicosin phosphate) was 
found in the lungs in all research periods, much less in the liver and least in the kidneys, heart, and pectoral muscles.

The tilmicosin phosphate distribution in the maximum amounts in the lungs indicates its organ affiliation and minor fluctuations in the drug concentration during different research periods - the lack of cumulative properties.

In a day (120 hours of the experiment) after discontinuation of Tilmox $25 \%$ solution in broiler chickens with ornithobacteriosis, the tilmicosin phosphate content in the lungs, liver, kidneys, heart, and pectoral muscles was $53 \%, 50,57,68$, and $34 \%$, respectively, up to 96 hours. Residual amounts of tilmicosin phosphate in the avian internal organs $-50 \%$ or more in a day after discontinuation of feeding tilmox solution indicate a long half-life, and hence a long antimicrobial effect.

The high sensitivity of Ornithobacterium rhinotracheale culture to tilmicosin and its maximum distribution in the lung tissue in broiler chickens with ornithobacteriosis, gives reason to recommend Tilmox 25\% for practical use.

In four days after Tilmox 25\% application to broiler chickens with ornithobacteriosis, only hyperemia in the lungs was observed, and no changes in the trachea, which are signs of the microscopic structure restoration.

To study the pharmacokinetic characteristics of antibiotics of other groups in broiler chickens with ornithobacteriosis are the prospects for our further research.

\section{References}

Abu-Basha, E., Idkaidek, N., \& Al-Shunnaq, A. (2007). Pharmacokinetics of tilmicosin (provitil powder and pulmotil liquid ac) oral formulations in chickens. Veterinary research communications, 31(4), 477-485. doi: 10.1007/s11259-006-3543-6
Avci, T., \& Elmas, M. (2014). Milk and blood pharmacokinetics of tylosin and tilmicosin following parenteral administrations to cows. Science world journal, 2014:869096. doi: 10.1155/2014/869096

Dimitrova, D., Petkov, P., \& Tsoneva, D. (2012). Pharmacokinetics of tilmicosin in calves after single subcutaneous application. Agricultural science and technology, 4(3), 211-214.

El-Ela, F. I. A., El-Banna, H. A., El-Deen, M. B., El-Gendy, A. A., \& Tohamy, M. A. (2015). Pharmacokinetics of Tylvalosin alone or in combination with Vitamin $\mathrm{E}$ in broiler chickens. Asian journal of animal and veterinary advances, 10(10), 556-566. doi: 10.3923/ ajava.2015.556.566

El-Mahmoudy, A., \& Gheith, I. (2016). The anti-nociceptive potential of tilmicosin against chemical-induced but not thermal-induced pain in mice. Internet journal immunopathology pharmacology, 29(1), 9-16. doi: 10.1177/0394632015593232.

Evans, T., \& Chapple, N. (2002). The animal health market. Nature reviews drug discovery, 1(12), 937-938. doi: 10.1038/nrd975

Keles, O., Bakirel, T., Sener, S., Baktir, G., Dağoğlu, G., \& Özkan, O. (2001). Pharmacokinetics and tissue levels of tilmicosin in fowls. Turkish journal of veterinary and animal sciences, 25, 629-634. Retrieved from https:// journals.tubitak.gov.tr/veterinary/issues/ vet-01-25-4/vet-25-4-30-0010-17.pdf

Kowalski, C., Roliński, Z., Zań, R., \& Wawron, W. (2002). Pharmacokinetics of tylosin in broiler chickens. Polish journal of veterinary sciences, 5(3), 127-130.

1Li, B., Gong, S.-Y., Zhou, X.-Z., Yang, Y.-J., Li, J.-Y., Wei, X.-J., ... \& Zhang, J.-Y. (2017). Determination of antibacterial agent tilmicosin in pig plasma by LC/MS/MS and its application to pharmacokinetics. Biomed chromatography, 31(3). doi: 10.1002/bmc.3825.

2Li, B., Zhou, X.-Z., Niu, J.-R., Wei, X.-J., Li, J.-Y., Yang, Y.-J., Liu, X.-W., Cheng, F.-S., \& Zhang., J.-Y. (2017). Efficacy and safety of ban huang oral liquid for treating bovine respiratory diseases. 
Complement alternative medecine, 14(2), 4759. doi: 10.21010/ajtcam.v14i2.6.

Li, J. C. (2003). Studies on stability of Tilmicosin solution and pharmacokinetics of Tilmicosin in broiler chicken. Master's thesis, China Agricultural University, Basic Veterinary Science. Lalonde, R. L., Kowalski, K. G., Hutmacher, M. M., Ewy, W., Nichols, D. J., Milligan, P. A., ... \& Miller, R. (2007). Model-based drug development. Clinical pharmacology \& therapeutics, 82(1), 21-32. doi: 10.1038/sj.clpt.6100235

McClary, D. G., Loneragan, G. H., \& Shryock, T. R. (2011). Relationship of in vitro minimum inhibitory concentrations of tilmicosin against Mannheimia haemolytica and Pasteurella multocida and in vivo tilmicosin treatment outcome among calves with signs of bovine respiratory disease. Journal Veterinary medecine associacion, 239(1), 129-135. doi: 10.2460/javma.239.1.129

Moore, G. M., Basson, R. P., \& Tonkinson, L. V. (1996). Clinical field trials with tilmicosin phosphate in feed for the control of naturally acquired pneumonia caused by Actinobacillus pleuropneumoniae and Pasteurella multocida in swine. American journal of veterinary research, 57(2), 224-228.

Ronald, G., \& Daniel, S. (2014). Pharmacologic modeling. Development of innovative drugs via modeling with MATLAB, 87-141. doi: 10.1007/978-3-642-39765-3
Shen, J., Li C., Jiang, H., Zhang, S., Guo, P., Ding, S., Li, X. (2005). Pharmacokinetics of tilmicosin after oral administration in swine. American journal of veterinary research, 66(6), 1071-1074. doi: 10.2460/ajvr.2005.66.1071.

Timsit, E., Workentine, M., Crepieux, T., Miller, C., Regev-Shoshani, G., Schaefer, A., \& Alexander, T. (2017). Effects of nasal instillation of a nitric oxide-releasing solution or parenteral administration of tilmicosin on the nasopharyngeal microbiota of beef feedlot cattle at high-risk of developing respiratory tract disease. Residence veterinary science, $115,117-124$. doi: 10.1016/j.rvsc.2017.02.001122.

Zhang, L., Zhao, L., Liu, Y., Liu, J., \& Li, X. (2017). Pharmacokinetics of tilmicosin in healthy pigs and in pigs experimentally infected with Haemophilus Parasuis. Journal Veterinary Science, 18(4), 431-437. doi: 10.4142/ jvs.2017.18.4.431

Zhang, P., Zhang, C., Aragon, V., Zhouc, X., Zoud, M., Wua, C., \& Shena, Z. (2019). Investigation of Haemophilus parasuis from healthy pigs in China. Veterinary microbiology, 231, 40-44. doi: 10.1016/j.vetmic.2019.02.034

Ziv, G., Shem-Tov, M., Glickman, A., Winkler, M., \& Saran, A. (1995). Tilmicosin antibacterial activity and pharmacokinetics in cows. Journal veterinary pharmacology therapy, 18(5), 340-345. doi: 10.1111/j.13652885.1995.tb00601.x.

\section{А. М. ТИшківська, В. Б. ДУХНИЦьКИй (2021). НАДХОДЖЕННЯ ТА РОЗПОДІЛ ТИЛМІКОЗИНУ В ОРГАНІЗМІ КУРЧАТ-БРОЙЛЕРІВ, ХВОРИХ НА ОРНІТОБАКТЕРІОЗ.} Ukrainian Journal of Veterinary Sciences, 12(2): 46-58, https://doi.org/10.31548/ ujvs2021.02.005

Анотація. Одним з основних показників, що визначають ефрективність антибіотика в організмі, є його здатність проникати та накопичуватись у високих концентраціях у місцях патологічного процесу. У статті наведено результати досліджень надходження, розподілу та виведення тилмікозину фосфрату - діючої речовини антибіотика тилмокс $25 \%$ з організму курчат-бройлерів кросу КОББ-500, хворих на орнітобактеріоз. Встановлено, що через 24 год від початку випоювання розчину препарату тилмокс 25\% курчатам-бройлерам, хворим на орнітобактеріоз, найбільше тилмікозину фосфрату містилося в легенях, тоді як у печінці менше в 1,6 раза, нирках - у 3,0 раза, серцевому м'язі - у 3,4 раза, грудних м'язах - у 3,5 раза, 
ніж у легенях. Через 48 та 72 год вміст тилмікозину зростав в усіх досліджуваних органах, але закономірність його розподілу була такою ж, як і через 24 год. Вміст тилмікозину фосфату в легенях на 72 год досліду переважав вміст в печінці, нирках, серцевому та грудних м'язах відповідно в 1,8 раза, 2,7, 2,9 та 3,9 раза. На 96 год вміст тилмікозину був максимальним у грудних м'язах, нирках, печінці, легенях, лише в сериі його містилося дещо менше, ніж у попередні періоди досліджень. Отримані результати засвідчують органну приналежність тилмікозину фосфату до тканин легень у курчат-бройлерів, хворих на орнітобактеріоз. Через добу (на 120 год досліду) після припинення застосування тилмоксу 25\%, вміст тилмікозину фосрату в легенях, печінці, нирках, серцевому та грудних м'язах курчат-бройлерів становив відповідно 53\%, 50, 57, 68 та 34\% до показника на 96 год. Чутливість Ornithobacterium rhinotracheale до тилмікозину та його розподіл у максимальних кількостях у легенях курчат-бройлерів, хворих на орнітобактеріоз, забезпечувало лікувальний ефект, що підтверджено результатами мікроскопічних досліджень.

Дослідження щодо фармакокінетичних властивостей тилмікозину виконані, в основному, на здоровій птиці. Тому, оптимізація схем лікування вже відомих антибіотиків, яка буде грунтуватися на дослідженні фармакокінетичних і фармакодинамічних властивостей не тільки на клінічно здорових, але й на хворих організмах є актуальним та важливим питанням угалузі ветеринарної фармакології.

Ключові слова: тилмокс 25\%, тилмікозину фосфат, курчата-бройлери, орнітобактеріоз, Ornithobacterium rhinotracheale, фармакокінетика, розподіл, накопичення, виведення 